\title{
Markers of early renal changes induced by industrial pollutants. II Application to workers exposed to lead
}

\author{
A Cárdenas, H Roels, A M Bernard, R Barbon, J P Buchet, R R Lauwerys, J Roselló, I Ramis, \\ A Mutti, I Franchini, L M Fels, $H$ Stolte, M E De Broe, G D Nuyts, S A Taylor, R G Price
}

\begin{abstract}
The present study has been carried out in the framework of a collaborative research project on the development of new markers of nephrotoxicity. A battery of more than 20 potential indicators of renal changes has been applied to 50 workers exposed to lead $(\mathrm{Pb})$ and 50 control subjects. After application of selection criteria 41 exposed and 41 control workers were eventually retained for the final statistical analysis. The average blood $\mathrm{Pb}$ concentration of exposed workers was $480 \mu \mathrm{g} / 1$ and their mean duration of exposure was 14 years. The battery of tests included parameters capable of detecting functional deficits (for example, urinary proteins of low or high molecular weight), biochemical alterations (for example, urinary eicosanoids, glycosaminoglycans, sialic acid) or cell damage (for example, urinary tubular antigens or enzymes) at different sites of the nephron or the kidney. The most outstanding effect found in workers exposed to $\mathbf{P b}$ was an interference with the renal synthesis of eicosanoids, resulting in lower urinary excretion of 6-keto-PGF $F_{1 x}$ and an enhanced excretion of thromboxane $\left(\mathrm{TXB}_{2}\right)$. The health sig-
\end{abstract}

Unité de Toxicologie Industrielle et Médecine du Travail, Faculté de Médecine, Université Catholique de Louvain

A Cárdenas, H Roels, A M Bernard, R Barbon, J P Buchet, R Lauwerys

Departamento de Neuroquímica, Laboratorio de Eicosanoides, CID-CSIC, Barcelona, Spain

I Ramis, J Roselló

Laboratorio di Tossicologia Industriale, Università degli Studi di Parma, Parma, Italy

A Mutti, I Franchini

Abteilung für Nephrologie, Medizinische Hochschule Hannover, Hannover, Germany

L M Fels, H Stolte

Department of Nephrology-Hypertension, University of Antwerp, Edegem-Antwerp, Belgium

$M$ E De Broe, G D Nuyts

Biochemistry Section, Biomolecular Sciences, King's College, London, United Kingdom S A Taylor, R G Price nificance of these biochemical alterations, detectable at low exposure to $\mathrm{Pb}$ is unknown. As they were not associated with any sign of renal dysfunction, they may represent reversible biochemical effects or only contribute to the degradation of the renal function from the onset of clinical $\mathrm{Pb}$ nephropathy. The urinary excretion of some tubular antigens was also positively associated with duration of exposure to $\mathrm{Pb}$. Another effect of $\mathbf{P b}$ that might deserve further study is a significant increase in urinary sialic acid concentration.

(British Journal of Industrial Medicine 1993;50:28-36)

Excessive exposure to lead $(\mathrm{Pb})$ may cause acute or chronic nephrotoxic effects. ${ }^{1-10}$ Acute $\mathrm{Pb}$ nephropathy is characterised functionally by a generalised deficit of tubular transport mechanisms (Fanconi syndrome) and morphologically by the appearance of degenerative changes in the tubular epithelium and nuclear inclusion bodies containing $\mathrm{Pb}$ protein complexes. ${ }^{10-12}$ These effects, which are usually reversible with chelation therapy, have been reported mainly in children..$^{9-12}$ Chronic $\mathrm{Pb}$ nephropathy is an irreversible renal disease that develops over months or years of excessive exposure and which may be associated with gout and hypertension..$^{9-113}$ This has been reported in adults who had ingested leaded paint during childhood (Queensland, Australia), who had consumed illicitly distilled alcohol ("moonshine whisky"), or who had a long history of occupational exposure. ${ }^{91012} 14$ In the chronically exposed adult, $\mathrm{Pb}$ nephropathy occurs as a progressive tubulointerstitial nephritis that is difficult to diagnose at the early stage. Indeed incipient $\mathrm{Pb}$ nephropathy is not associated with urine abnormalities easily detected by dipsticks. Tests evaluating the glomerular filtration rate (creatinine clearance, blood urea nitrogen, or serum creatinine) are the only ones which presently can be used to detect renal effects caused by occupational exposure to $\mathrm{Pb} .{ }^{91516}$ But when these tests are abnormal, then nephropathy has already reached an irreversible phase that may lead to renal insufficiency.$^{16}$ More sensitive markers would be useful 
to ensure that occupational exposure levels to $\mathrm{Pb}$ currently prevailing in the industry do not entail a risk for renal function

One of the metals examined in the framework of a collaborative research project on the development and validation of new markers of nephrotoxicity was $\mathrm{Pb}$. In this project we investigated more than 20 potential markers of renal effects that can be arbitrarily classified into three broad categoriesnamely, functional markers (for example, urinary proteins), cytotoxicity markers (for example, tubular antigens), and biochemical markers (for example, eicosanoids). These markers were applied to a cohort of 50 workers moderately exposed to $\mathrm{Pb}$ to assess whether they may be useful for the early detection of renal effects caused by this metal.

\section{Subjects and methods}

STUDY POPULATION

The control and exposed workers recruited for this study, 50 in each group, were employed in a $\mathrm{Pb}$ smelter in Belgium. To be included in the exposed group, workers should have at the time of examination a blood $\mathrm{Pb}$ concentration $(\mathrm{Pb}-\mathrm{B})$ above $350 \mu \mathrm{g} / 1$ with a duration of exposure of at least one year. The control and exposed groups were then subjected to a careful selection (see reference 17 for a detailed description of the criteria) to exclude subjects whose renal function might be altered by causes other than $\mathrm{Pb}$. Forty one workers were finally retained in each cohort.

\section{METHODS}

Blood and urine samples were collected as described in the paper on the mercury cohort. ${ }^{1 \overline{7}}$ An identical battery of tests was also applied comprising: in blood, lead and zinc protoporphyrin (ZPP) concentrations, alcian blue (AB) binding to red blood cell (RBC) surfaces, sialic acid content of RBC membranes; in serum or plasma, creatinine (crt-S), $\beta_{2}$-microglobulin $\left(\beta_{2}-\mathrm{m}\right)$, anti-GBM antibody (anti-GBM) and sialic acid concentrations; and in urine, cadmium (Cd-U), mercury $(\mathrm{Hg}-\mathrm{U})$, sodium, creatinine (crt$\mathrm{U})$, albumin, transferrin, immunoglobulin (IgG), $\beta_{2}-$ $\mathrm{m}$, retinol binding protein (RBP), protein 1 , TammHorsfall glycoprotein (THG), fibronectin, 6-ketoprostaglandin $\mathrm{F}_{1 x}$ (6-keto-PGF $\mathrm{F}_{1 x}$ ), prostaglandin $\mathrm{E}_{2}$ $\left(\mathrm{PGE}_{2}\right)$, prostaglandin $\mathrm{F}_{2 x}\left(\mathrm{PGF}_{2 x}\right)$, thromboxane $\mathrm{B}_{2}$ $\left(\mathrm{TXB}_{2}\right)$, sialic acid, glycosaminoglycan (GAG), the brush border antigens (BBA, BB50 and HF5) concentrations, $\mathrm{pH}$, and activities of kallikrein, intestinal alkaline phosphatase (IAP), tissue nonspecific alkaline phosphatase (TNAP), and N-acetyl$\beta$-D-glucosaminidase (NAG). The urinary concentration of $\delta$-aminolaevulinic acid (ALAU) was determined by an automated technique. ${ }^{18}$ Statistical analysis was performed as described earlier. ${ }^{17}$

\section{Results}

Table 1 shows the characteristics of the controls and workers exposed to $\mathrm{Pb}$. The duration of exposure ranged from two to 33 years (mean 14 years). Compared with the referents, the workers exposed to $\mathrm{Pb}$ were on average older and they excreted more creatinine and cadmium in urine but less mercury. The smoking and drinking habits of the two groups were similar. In the control workers ZPP concentra-

Table 1 Characteristics of control and workers exposed to $\mathrm{Pb}$

\begin{tabular}{|c|c|c|c|c|c|}
\hline & \multicolumn{2}{|c|}{ Control workers $(n=41)$} & \multicolumn{2}{|c|}{ Exposed workers $(n=41)$} & \multirow[b]{2}{*}{ p Value ${ }^{\star}$} \\
\hline & Mean or No & $S D$ or (range) & Mean or No & $S D$ or (range) & \\
\hline Age $(y)$ & $35 \cdot 0$ & $8 \cdot 1$ & $39 \cdot 0$ & $9 \cdot 2$ & $<0.05$ \\
\hline Body mass index & $24 \cdot 4$ & $3 \cdot 5$ & $25 \cdot 4$ & $3 \cdot 2$ & NS \\
\hline Smokers & 15 & & 21 & & NS \\
\hline Duration (y) & $14 \cdot 1$ & $9 \cdot 2$ & $16 \cdot 7$ & $6 \cdot 8$ & NS \\
\hline Cigarettes/day & $12 \cdot 9$ & $5 \cdot 6$ & $17 \cdot 2$ & $10 \cdot 4$ & NS \\
\hline Alcohol drinkers & 26 & & 25 & & NS \\
\hline Glasses/week & $14 \cdot 7$ & $9 \cdot 2$ & $17 \cdot 9$ & $12 \cdot 4$ & NS \\
\hline Exposure (y) & - & & $14 \cdot 0$ & $7 \cdot 0$ & - \\
\hline $\mathrm{Pb}-\mathrm{B}(\mu \mathrm{g} / \mathrm{l})$ & 167 & $(63-343)$ & 480 & $(363-646)$ & $<0.0001$ \\
\hline $\mathrm{ZPP}$ in blood $\dagger(\mu \mathrm{g} / \mathrm{g} \mathrm{Hb})$ & $1 \cdot 12$ & $(0 \cdot 60-3 \cdot 1)$ & $3 \cdot 41$ & $(1 \cdot 30-13 \cdot 6)$ & $<0.001$ \\
\hline ALA in urine $+(\mathrm{mg} / \mathrm{l})$ & $5 \cdot 1$ & $(1 \cdot 4-11 \cdot 6)$ & $7 \cdot 6$ & $(1 \cdot 2-40 \cdot 6)$ & $<0.01$ \\
\hline ALA in urinet ( $\mathrm{mg} / \mathrm{g}$ creatinine) & $4 \cdot 8$ & $(3 \cdot 0-8 \cdot 1)$ & $5 \cdot 8$ & $(3 \cdot 2-17 \cdot 9)$ & $<0.01$ \\
\hline $\mathrm{Cd}$ in urinet $(\mu \mathrm{g} / \mathrm{l})$ & $0 \cdot 43$ & $(0 \cdot 08-1 \cdot 86)$ & $1 \cdot 17$ & $(0 \cdot 37-1 \cdot 86)$ & $<0.001$ \\
\hline Cd in urinet ( $\mu \mathrm{g} / \mathrm{g}$ creatinine $)$ & $0 \cdot 40$ & $(0 \cdot 30-1 \cdot 90)$ & $0 \cdot 88$ & $(0 \cdot 30-1 \cdot 90)$ & $<0.001$ \\
\hline $\mathrm{Hg}$ in urine ${ }^{\prime}(\mu \mathrm{g} / \mathrm{l})$ & $2 \cdot 5$ & $(1 \cdot 4-7 \cdot 1)$ & $2 \cdot 3$ & $(1 \cdot 3-6 \cdot 8)$ & NS \\
\hline $\mathrm{Hg}$ in urinet $(\mu \mathrm{g} / \mathrm{g}$ creatinine $)$ & $2 \cdot 3$ & $(1 \cdot 0-4 \cdot 7)$ & $1 \cdot 7$ & $(0 \cdot 8-4 \cdot 9)$ & $<0.01$ \\
\hline Creatinine in urine $(\mathrm{g} / \mathrm{l})$ & $1 \cdot 18$ & $(0 \cdot 40-2 \cdot 41)$ & 1.56 & $(0 \cdot 31-3 \cdot 51)$ & $<0.05$ \\
\hline
\end{tabular}

^Student's $t$ test or $\chi^{2}$ test.

tGeometric means. 
Table 2 Significant associations found by multiple regression analysis

\begin{tabular}{|c|c|c|c|c|}
\hline Dependent variables $\star$ & $\begin{array}{l}\text { Independent } \\
\text { variables }^{\star}\end{array}$ & $\begin{array}{l}\text { Partial regression } \\
\text { coefficient }\end{array}$ & Partial $r^{2}$ & $p$ Value \\
\hline \multicolumn{5}{|l|}{ Urine: } \\
\hline Albumin & Crt-U & 0.813 & $0 \cdot 381$ & 0.0001 \\
\hline Transferrin & Crt-U & $0 \cdot 864$ & 0.304 & 0.0001 \\
\hline IgG & Crt-U & $0 \cdot 701$ & $0 \cdot 306$ & 0.0001 \\
\hline \multirow[t]{2}{*}{$\beta_{2}-\mathrm{m}$} & Crt-U & 0.456 & $0 \cdot 123$ & 0.0007 \\
\hline & $\mathrm{BMI}$ & -0.035 & $0 \cdot 101$ & 0.0037 \\
\hline RBP & Crt-U & 0.954 & 0.634 & 0.0001 \\
\hline Protein 1 & Crt-U & $0 \cdot 834$ & 0.302 & 0.0001 \\
\hline THG & Crt-U & $1 \cdot 238$ & $0 \cdot 820$ & 0.0001 \\
\hline NAG & Crt-U & 0.576 & $0 \cdot 410$ & $0 \cdot 0001$ \\
\hline \multirow[t]{2}{*}{ BB50† } & Crt-U & 0.652 & $0 \cdot 246$ & 0.0001 \\
\hline & BMI & -0.017 & 0.036 & $0 \cdot 0492$ \\
\hline $\mathrm{BBA} \dagger$ & Crt-U & 0.481 & $0 \cdot 165$ & 0.0002 \\
\hline HF5 ${ }^{\dagger}$ & Crt-U & 0.543 & $0 \cdot 178$ & 0.0001 \\
\hline IAP & Crt-U & $1 \cdot 084$ & 0.392 & $0 \cdot 0001$ \\
\hline \multirow[t]{2}{*}{ TNAP } & Crt-U & $1 \cdot 863$ & $0 \cdot 266$ & 0.0001 \\
\hline & $\mathrm{BMI}$ & -0.054 & 0.050 & 0.0186 \\
\hline Fibronectin & Crt-U & $0 \cdot 320$ & $0 \cdot 309$ & 0.0001 \\
\hline \multirow{2}{*}{ 6-keto-PGF $1 x$} & Crt-U & 0.603 & 0.524 & 0.0001 \\
\hline & $\mathrm{Pb}-\mathrm{B}$ & $-0 \cdot 179$ & 0.056 & 0.0018 \\
\hline \multirow[t]{2}{*}{$\mathrm{PGE}_{2}$} & Crt-U & 0.625 & $0 \cdot 241$ & 0.0001 \\
\hline & $\mathrm{BMI}$ & -0.018 & 0.048 & $0 \cdot 0258$ \\
\hline $\mathrm{PGF}_{2 x}$ & Crt-U & $1 \cdot 208$ & 0.563 & 0.0001 \\
\hline \multirow[t]{2}{*}{$\mathrm{TXB}_{2}$} & Crt-U & 0.486 & 0.355 & 0.0001 \\
\hline & $\mathrm{Pb}-\mathrm{B}$ & 0.360 & $0 \cdot 170$ & 0.0001 \\
\hline Kallikrein & Crt-U & 0.910 & 0.499 & 0.0001 \\
\hline GAG & Crt-U & $0 \cdot 700$ & 0.787 & 0.0001 \\
\hline \multirow[t]{2}{*}{ Sialic acid } & Crt-U & 0.921 & 0.526 & 0.0001 \\
\hline & ZPP & 0.205 & 0.037 & 0.0118 \\
\hline \multirow[t]{2}{*}{$\mathrm{pH}$ urine } & BMI & -0.096 & 0.229 & 0.0001 \\
\hline & Crt-U & -1.073 & $0 \cdot 105$ & 0.0007 \\
\hline
\end{tabular}

$\star \mathrm{Pb}-\mathrm{B}, \mathrm{ZPP}$, and urinary variables were $\log$ transformed. All urinary parameters were expressed per litre. †Correlated with duration of exposure in the exposed group.

For abbreviations see subjects and methods section.

tions did not exceed the upper normal value of $2 \cdot 5$ $\mu \mathrm{g} / \mathrm{g} \mathrm{Hb}$, except in one worker $(3 \cdot 1 \mu \mathrm{g} / \mathrm{g} \mathrm{Hb})$. The workers exposed to $\mathrm{Pb}$ showed significantly increased ZPP and ALAU concentrations compared with the control group. The different indicators of exposure to $\mathrm{Pb}$ were positively related to each other. Pearson's correlation coefficients $(p<0.001)$ and regression lines (within parentheses) were calculated on the total population $(\mathrm{n}=82): \mathrm{r}=0.80$ between $\mathrm{ZPP}$ and $\mathrm{Pb}$ B $(\log \mathrm{ZPP}=-2 \cdot 12+9.98 \log \mathrm{Pb}-\mathrm{B})$; $\mathrm{r}=0.52$ between ALAU (factored for creatinine) and ZPP $(\log$ ALAU $=0.65+0.240 \log \mathrm{ZPP})$; and $\mathrm{r}$ $=0.38$ between ALAU and $\mathrm{Pb}-\mathrm{B}(\log \mathrm{ALAU}=0.19$ $+0.218 \log \mathrm{Pb}-\mathrm{B})$. No relation existed between $\mathrm{Pb}-\mathrm{B}$ or ZPP and the duration of exposure.

No statistically significant association was found between the renal variables and age in the control group. Multivariate correlation analysis on the total population $(n=82)$ showed that the excretions of 6keto-PGF ${ }_{1 \alpha}$ and $\mathrm{TXB}_{2}$ in urine were significantly correlated with $\mathrm{Pb}-\mathrm{B}$ in a negative and positive fashion respectively, whereas the urinary excretion of sialic acid was positively associated with ZPP (table
2). To assess the influence of the duration of exposure on the renal parameters a multivariate correlation analysis was also performed on the $\mathrm{Pb}$ workers. Only the tubular antigens $\mathrm{BB} 50, \mathrm{BBA}$, and $\mathrm{HF} 5$ were found to be significantly related to the duration of exposure.

After adjustment of the renal parameters for the interfering factors recorded in table 2 (mainly crt- $U$ and sometimes also body mass index (BMI)) the only significant findings in the workers exposed to $\mathrm{Pb}$ were an increase in the mean urinary excretion of $\mathrm{TXB}_{2}$, NAG, and sialic acid, and a decrease in 6-keto-PGF P $_{1 \alpha}$ (table 3). The comparison of prevalences of abnormal values (table 4) showed a similar pattern of changes with, in addition, a higher prevalence of reduced $\mathrm{PGE}_{2}$ values in urine in the workers exposed to $\mathrm{Pb}$.

Before standardisation for confounding factors, urinary $\mathrm{pH}$ was lower in workers exposed to $\mathrm{Pb}$ than in controls $(6.05 v 6.85$ in controls, $\mathrm{p}<0.01)$. This effect, however, was not significantly related to any marker of $\mathrm{Pb}$ exposure (table 2). It was probably responsible for some degradation of $\beta_{2}-\mathrm{m}$ as suggested by a significant correlation between both 
Table 3 Urinary and bloodborne markers of nephrotoxicity in control and workers exposed to $\mathrm{Pb}$

\begin{tabular}{|c|c|c|c|}
\hline Marker & $\begin{array}{l}\text { Control workers } \\
(n=41) \S \\
\text { Mean (SD or range) }\end{array}$ & $\begin{array}{l}\text { Exposed workers } \\
(n=41) \| \\
\text { Mean (SD or range) }\end{array}$ & p Value \\
\hline 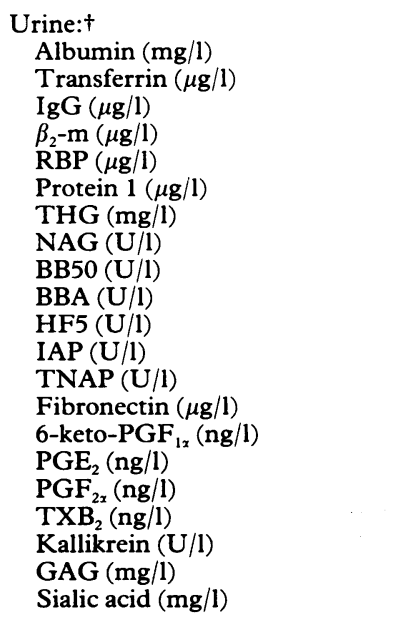 & $\begin{array}{c}5 \cdot 8(2 \cdot 6-53 \cdot 1) \\
215(83-2280) \\
1269(320-3682) \\
72(15-477) \\
64(35-238) \\
86(21-636) \\
16 \cdot 2(8 \cdot 8-41 \cdot 0) \\
1 \cdot 21(0 \cdot 49-2 \cdot 93) \\
9 \cdot 3(2 \cdot 8-34 \cdot 7) \\
7 \cdot 7(2 \cdot 7-28 \cdot 1) \\
6 \cdot 9(1 \cdot 2-30 \cdot 2) \\
0 \cdot 53(0 \cdot 14-2 \cdot 04) \\
0 \cdot 081(0 \cdot 005-0 \cdot 704) \\
14 \cdot 6(7 \cdot 5-28 \cdot 7) \\
180(120-270) \\
135(73-533) \\
192(65-501) \\
43(19-84) \\
0 \cdot 72(0 \cdot 17-2 \cdot 18) \\
38 \cdot 5(27 \cdot 3-52 \cdot 1) \\
215(106-1073)\end{array}$ & $\begin{array}{c}6 \cdot 5(3 \cdot 0-28 \cdot 5) \\
254(46-1234) \\
1189(338-4175) \\
57(13-170) \\
68(33-174) \\
95(16-332) \\
16 \cdot 6(9 \cdot 1-31 \cdot 0) \\
1 \cdot 56(0 \cdot 82-5 \cdot 21) \\
11 \cdot 0(2 \cdot 0-38 \cdot 8) \\
9 \cdot 0(2 \cdot 2-52 \cdot 5) \\
8 \cdot 2(3 \cdot 0-44 \cdot 9) \\
0 \cdot 54(0 \cdot 08-4 \cdot 49) \\
0 \cdot 091(0 \cdot 003-1 \cdot 40) \\
13 \cdot 8(8 \cdot 6-35 \cdot 6) \\
140(47-291) \\
118(41-412) \\
204(45-891) \\
69(33-133) \\
0 \cdot 75(0 \cdot 29-2 \cdot 08) \\
38 \cdot 3(17 \cdot 9-54 \cdot 0) \\
308(128-613)\end{array}$ & $\begin{array}{l}\text { NS } \\
\text { NS } \\
\text { NS } \\
\text { NS } \\
\text { NS } \\
\text { NS } \\
<0.01 \\
\text { NS } \\
\text { NS } \\
\text { NS } \\
\text { NS } \\
\text { NS } \\
\text { NS } \\
<0.001 \\
\text { NS } \\
\text { NS } \\
<0.001 \\
\text { NS } \\
\text { NS } \\
<0.01\end{array}$ \\
\hline $\begin{array}{l}\text { Blood: }+ \\
\text { Creatinine/serum (mg/l) } \\
\beta_{2}-\mathrm{m} / \text { serum }(\mathrm{mg} / \mathrm{l}) \\
\text { Sialic acid/plasma }(\mathrm{mg} / \mathrm{l}) \\
\text { Sialic acid/RBC }(\mu \mathrm{g} / \mathrm{mg} \text { protein }) \\
\text { AB binding/RBC }\left(\mathrm{ng} / 10^{6} \mathrm{RBC}\right) \\
\text { Anti-GBM/serum }(\mathrm{U} / \mathrm{l})\end{array}$ & $\begin{array}{c}10 \cdot 3(1 \cdot 0) \\
1 \cdot 37(0 \cdot 27) \\
708(157) \\
29 \cdot 3(5 \cdot 5) \\
184(25) \\
26 \cdot 6(6 \cdot 1)\end{array}$ & $\begin{array}{c}10 \cdot 2(1 \cdot 0) \\
1 \cdot 42(0 \cdot 34) \\
723(238) \\
28 \cdot 9(4 \cdot 4) \\
185(21) \\
24 \cdot 6(4 \cdot 9)\end{array}$ & $\begin{array}{l}\text { NS } \\
\text { NS } \\
\text { NS } \\
\text { NS } \\
\text { NS } \\
\text { NS }\end{array}$ \\
\hline
\end{tabular}

*Student's $t$ test.

+Geometric means; †Arithmetic means.

$\S$ For PGE $_{2} \mathrm{n}=39$.

For $\mathrm{PGE}_{2}$ and kallikrein $\mathrm{n}=\mathbf{4 0}$ and 38 respectively.

For abbreviations see subjects and methods section.

All the markers of nephrotoxicity were standardised for the determinants unrelated to $\mathrm{Pb}$ exposure (see table 2). Standardisation was based on the mean of the total population.

variables $\left(\mathrm{r}=0.68, \mathrm{p}=0.0001 ; \log \beta_{2}-\mathrm{m}\right.$ $=-0.77+3.09 \log \mathrm{pH})$. In the multivariate analysis, $48 \%$ of the variance in $\beta_{2}-\mathrm{m}$ excretion was explained by urinary $\mathrm{pH}$. This again confirms that making urine alkaline after collection is not a satisfactory procedure for avoiding the degradation of $\beta_{2}-\mathrm{m}$.

The exposed workers were divided into two subgroups according to $\mathrm{Pb}-\mathrm{B} \quad(\mathrm{Pb}-\mathrm{B} \leqslant 500$ and $\mathrm{Pb}-\mathrm{B}>500 \mu \mathrm{g} / \mathrm{l})$ and $\mathrm{ZPP}(\mathrm{ZPP} \leqslant 5$ and ZPP $>5$ $\mu \mathrm{g} / \mathrm{g} \mathrm{Hb})$ and the prevalences of abnormal values were compared (figs 1 and 2). A few parameters showed a tendency for a dose-response relation such as the increased urinary excretion of sialic acid with $\mathrm{Pb}-\mathrm{B}$ and $\mathrm{ZPP}$, and the decreased excretion of 6keto-PGF ${ }_{1 \alpha}$ and $\mathrm{PGE}_{2}$ with $\mathrm{ZPP}$.

\section{Discussion}

Renal effects of $\mathrm{Pb}$, consisting mainly in a decline of the glomerular filtration rate without proteinuria, have been reported in workers with longstanding exposure to $\mathrm{Pb}$ and with $\mathrm{Pb}-\mathrm{B}$ of $600 \mu \mathrm{g} / 1$ or more. ${ }^{1-8}$ So far, studies conducted on populations of workers with lower levels of exposure to $\mathrm{Pb}$ have disclosed no renal effect or only infraclinical changes of marginal significance. ${ }^{14}$ 19-22 The cohort of workers examined in the present study had an average $\mathrm{Pb}-\mathrm{B}$ of $480 \mu \mathrm{g} / \mathrm{l}$ and only three workers had a value above $600 \mu \mathrm{g} / 1$ (highest value $646 \mu \mathrm{g} / \mathrm{l}$ ). After standardisation for factors unrelated to $\mathrm{Pb}$ exposure, three renal effectsnamely, a reduced urinary excretion of 6-keto-PGF ${ }_{1 \alpha}$ and an increased excretion of $\mathrm{TXB}_{2}$ and sialic acid (table 2) were found to be statistically associated with Pb-B or ZPP. No statistically significant changes in the urinary excretion of tubular antigens or specific low or high molecular weight proteins were found. The urinary excretion of the tubular antigens BB50, BBA, and HF5, however, was related to the duration 
Table 4 Prevalences of abnormal values of urinary and bloodborne markers of nephrotoxicity in controls and workers exposed to $\mathrm{Pb}$

\begin{tabular}{|c|c|c|c|c|c|c|}
\hline Marker & Cut off valuet & \multicolumn{2}{|c|}{$\begin{array}{l}\text { Control workers } \\
(n=41)_{\ddagger}^{\ddagger}\end{array}$} & \multicolumn{2}{|c|}{$\begin{array}{l}\text { Exposed workers } \\
(n=41) \S\end{array}$} & $p$ Value $e^{\star}$ \\
\hline \multicolumn{7}{|l|}{ Urine: $†$} \\
\hline Albumin & $>12 \cdot 2$ & 2 & $(4 \cdot 9)$ & 8 & $(19 \cdot 5)$ & NS \\
\hline Transferrin & $>567$ & 2 & $(4 \cdot 9)$ & 8 & $(19 \cdot 5)$ & NS \\
\hline IgG & $>3141$ & 2 & $(4.9)$ & 1 & $(2 \cdot 4)$ & NS \\
\hline$\beta_{2}-\mathrm{m}$ & $>164$ & 2 & $(4.9)$ & 1 & $(2 \cdot 4)$ & NS \\
\hline RBP & $>101$ & 2 & $(4 \cdot 9)$ & 7 & $(17 \cdot 1)$ & NS \\
\hline Protein 1 & $>271$ & 2 & $(4.9)$ & 3 & $(7 \cdot 3)$ & NS \\
\hline THG & $>28 \cdot 1$ & 2 & $(4 \cdot 9)$ & 1 & $(2 \cdot 4)$ & NS \\
\hline NAG & $>2 \cdot 21$ & 2 & $(4.9)$ & 4 & $(9 \cdot 8)$ & NS \\
\hline BB50 & $>18.6$ & 2 & $(4.9)$ & 7 & $(17 \cdot 1)$ & NS \\
\hline BBA & $>17.6$ & 2 & $(4 \cdot 9)$ & 5 & $(12 \cdot 2)$ & NS \\
\hline HF5 & $>17 \cdot 8$ & 2 & $(4.9)$ & 4 & $(9 \cdot 8)$ & NS \\
\hline IAP & $>1.56$ & 2 & $(4 \cdot 9)$ & 4 & $(9 \cdot 8)$ & NS \\
\hline TNAP & $>0.48$ & 2 & $(4.9)$ & 6 & $(14 \cdot 6)$ & NS \\
\hline Fibronectin & $>19.8$ & 2 & $(4.9)$ & 2 & $(4 \cdot 9)$ & NS \\
\hline 6-keto-PGF $F_{1 x}$ & $<135$ & 2 & $(4.9)$ & 16 & $(39 \cdot 0)$ & $<0.001$ \\
\hline $\mathrm{PGE}_{2}$ & $<77$ & 2 & $(5 \cdot 1)$ & 10 & $(25 \cdot 0)$ & $<0.05$ \\
\hline $\mathrm{PGF}_{2 x}$ & $<79$ & 2 & $(4 \cdot 9)$ & 5 & $(12 \cdot 2)$ & NS \\
\hline $\mathrm{TXB}_{2}$ & $>77$ & 2 & $(4 \cdot 9)$ & 16 & $(39 \cdot 0)$ & $<0.001$ \\
\hline Kallikrein & $<0.36$ & 2 & $(4.9)$ & 4 & $(10 \cdot 5)$ & NS \\
\hline GAG & $>51$ & 2 & $(4.9)$ & 4 & $(9 \cdot 8)$ & NS \\
\hline Sialic acid & $>380$ & 2 & $(4 \cdot 9)$ & 21 & $(51 \cdot 2)$ & $<0.0001$ \\
\hline \multicolumn{7}{|l|}{ Blood: } \\
\hline Creatinine/serum & $>11 \cdot 7$ & 2 & $(4 \cdot 9)$ & 2 & $(4 \cdot 9)$ & NS \\
\hline$\beta_{2}-\mathrm{m} /$ serum & $>1 \cdot 88$ & 2 & $(4 \cdot 9)$ & 4 & $(9 \cdot 8)$ & NS \\
\hline Sialic acid/plasma & $>958$ & 2 & $(4 \cdot 9)$ & 6 & $(14 \cdot 6)$ & NS \\
\hline Sialic acid/RBC & $<21.9$ & 2 & $(4.9)$ & 3 & $(7 \cdot 3)$ & NS \\
\hline AB binding/RBC & $<150$ & 2 & $(4 \cdot 9)$ & 1 & $(2 \cdot 4)$ & NS \\
\hline Anti-GBM/serum & $>36.7$ & 3 & $(7 \cdot 3)$ & 0 & - & NS \\
\hline
\end{tabular}

«Fisher's exact test.

†For units see table 3 and for abbreviations see subjects and methods section.

$\ddagger$ For $\mathrm{PGE}_{2} \mathrm{n}=39$.

$\S$ For $\mathrm{PGE}_{2}$ and kallikrein $\mathrm{n}=40$ and 38 respectively.

All the markers of nephrotoxicity were standardised for the determinants unrelated to $\mathrm{Pb}$ exposure (see table 2). Standardisation was based on the mean of the total population.

of exposure. Hence, a slight tubulotoxic effect of $\mathrm{Pb}$ cannot be formally excluded. ${ }^{23}$

An intriguing finding was the slightly increased urinary NAG activity in workers exposed to $\mathrm{Pb}$ (table 3). This seems to agree with three cross sectional studies in which a significant increase in activity of NAG was found in workers with mean $\mathrm{Pb}-\mathrm{B}$ values below $600 \mu \mathrm{g} / 1 .{ }^{24-26}$ Besides the fact that the increased urinary activity of NAG was not always dose related ${ }^{24}$ or uncorrected for diuresis, ${ }^{25}$ these studies did not take into account the simultaneous exposure to cadmium that occurs frequently in $\mathrm{Pb}$ smelters. Actually, in the present study we implicitly assumed that cadmium would not cause renal effects when Cd$\mathrm{U}$ did not exceed $2 \mu \mathrm{g} / \mathrm{g}$ creatinine as suggested by studies on cadmium workers ${ }^{27}$ and in the general population. ${ }^{28}$ The prevalence of abnormal NAG values was not, however, correlated with $\mathrm{Pb}-\mathrm{B}$ (fig 1 ) or ZPP (fig 2), nor with duration of exposure to $\mathrm{Pb}$.
Furthermore, a positive association was found with Cd-U $(\log$ NAG $=0.18+0.20 \log \mathrm{Cd}-\mathrm{U}(\mu \mathrm{g} / \mathrm{g}$ creatinine), $\mathrm{r}=0.39, \mathrm{p}<0.0005)$. In another study on workers exclusively exposed to $\mathrm{Pb}$ (without concomitant increased Cd-U) no significant change in activity of NAG was found (unpublished results). Taken together, the results suggest that the increase in activity of NAG found in the present and other studies among workers exposed to $\mathrm{Pb}^{24-26}$ might be caused by a combined effect of $\mathrm{Pb}$ and cadmium. It is also possible that the association between $\mathrm{Cd}-\mathrm{U}$ and NAG activity was simply the expression of a simultaneous increase in cadmium and NAG excretion as the result of some tubular changes induced by $\mathrm{Pb}{ }^{29}$

The absence of change in the urinary excretion of low molecular weight proteins is in agreement with previous studies that failed to show an increase in $\beta_{2}-\mathrm{m}$ excretion even in workers highly exposed to lead. ${ }^{1519213031}$ The only exceptions are the studies of 

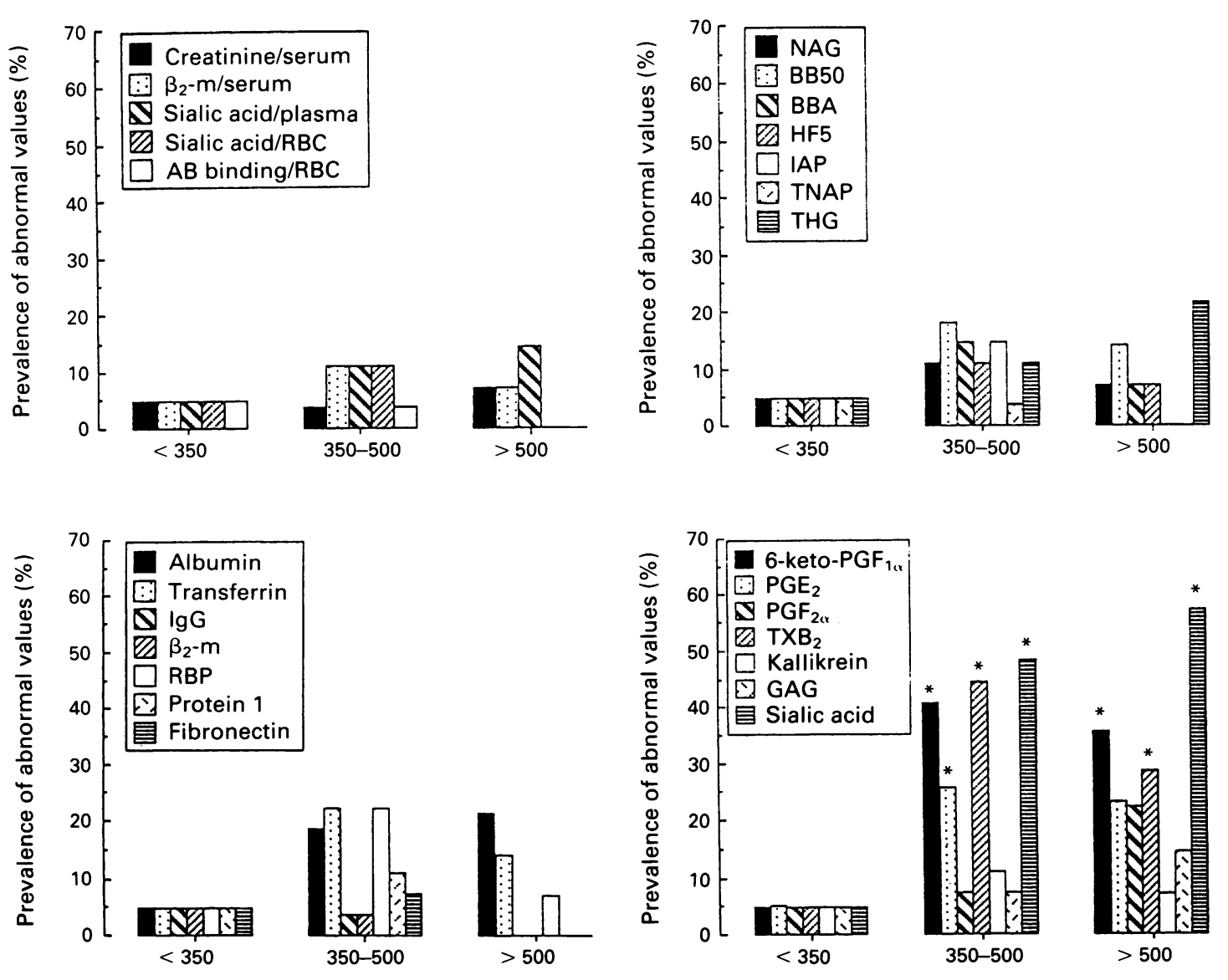

Lead in blood $(\mu \mathrm{g} / \mathrm{l})$

Figure 1 Prevalences of abnormal values of markers of nephrotoxicity as a function of Pb-B. Prevalences were established on the basis of the cut off values given in table 4 . The numbers of subjects in each group were 41 (controls: Pb-B $<350 \mu g / l$ ), $27(P b-B \leqslant 500 \mu g / l)$, and $14(P b-B>500 \mu g / l)$. The mean duration of exposure of the two Pb subgroups were $15 \cdot 6$ and 10.9 years respectively. ${ }^{*}$ Significantly different from the group with $P b-B<350 \mu \mathrm{g} / \mathrm{l}$.

Verschoor et $a l^{26}$ and of Huang et al. ${ }^{32}$ The last authors reported an increase in $\beta_{2}-\mathrm{m}$ excretion in workers exposed to $\mathrm{Pb}$ but this was not substantiated by a comparison with a matched control group and no attempt was made to correlate this effect with indicators of exposure to $\mathrm{Pb}$. Verschoor et al $^{26}$ found a slight increase in urinary RBP, but this was not correlated with the $\mathrm{Pb}-\mathrm{B}$ level and therefore might well be caused by another factor. In support of this Mason and co-workers ${ }^{33}$ found no increase in excretion of RBP in workers with chronic high exposure to $\mathrm{Pb}$.

The most interesting effects of exposure to $\mathrm{Pb}$ unravelled by the present study are the changes in the urinary excretion of eicosanoids, which likely reflect a disturbance in their synthesis. These changes might be involved in the progressive loss of renal function or in the development of hypertension seen in some subjects with a long history of excessive exposure to $\mathrm{Pb}$. Abnormalities in renal metabolism of prostaglandin and thromboxane may contribute to the pathophysiology of renal failure and hypertension. ${ }^{34}$ In essential hypertension, for instance, the urinary excretion of $\mathrm{PGE}_{2}$ and 6-keto-PGF $\mathrm{PG}_{1 x}$ (two vasodilatators) has been reported to be decreased whereas that of $\mathrm{TXB}_{2}$ (a vasoconstrictor derived from arachidonic acid) was increased. ${ }^{34}$ As well as a direct vasoactive action that results in an increased renal vascular resistance, the depletion of prostaglandins seems to enhance the retention of sodium and the pressor response to angiotensin II and vasopressin. ${ }^{34-37}$ Workers exposed to $\mathrm{Pb}$ seem to have 

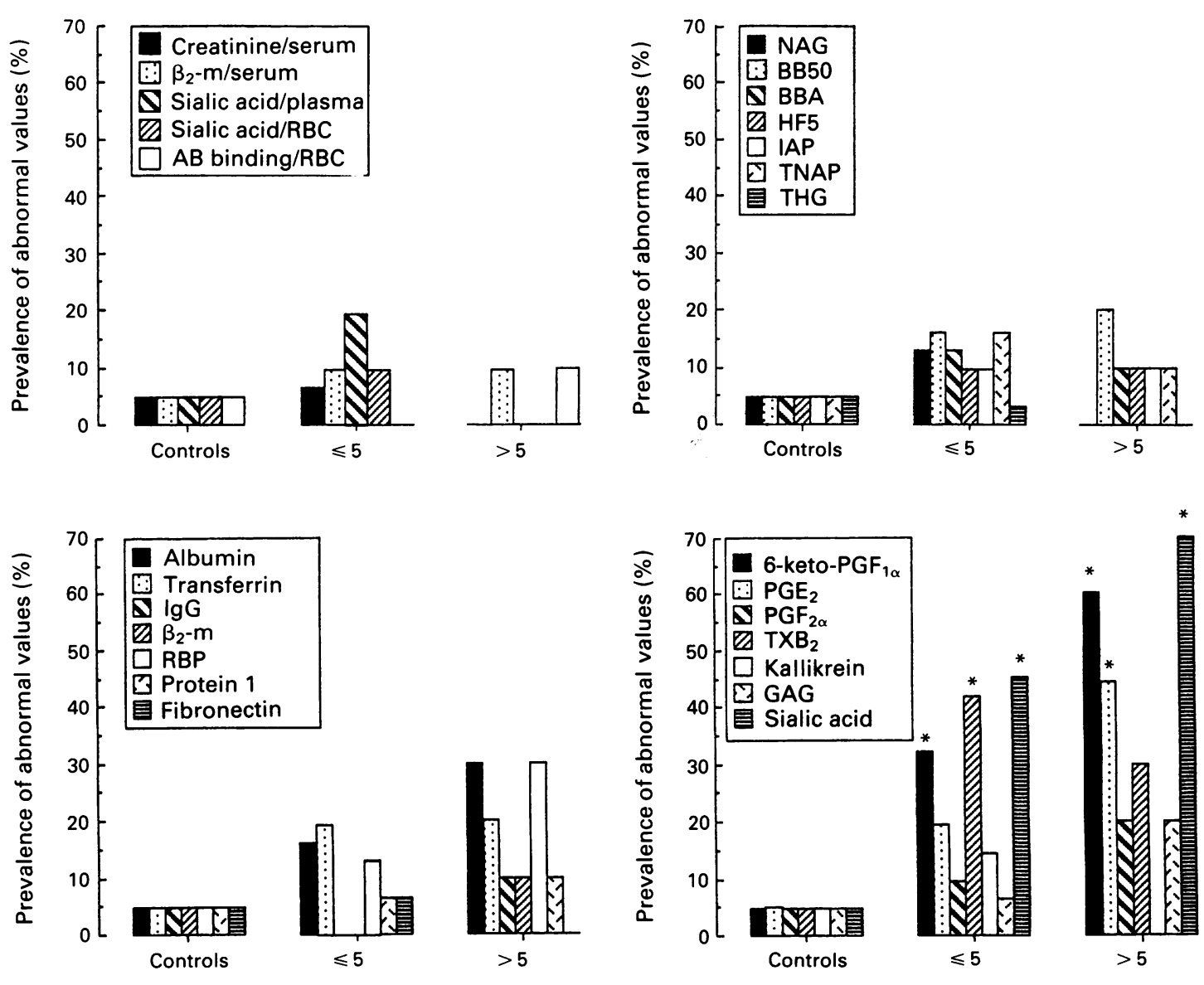

ZPP in blood of exposed workers $(\mu \mathrm{g} / \mathrm{g} \mathrm{Hb})$

Figure 2 Prevalences of abnormal values of markers of nephrotoxicity as a function of ZPP concentrations. Prevalences were established on the basis of the cut off values given in table 4. The numbers of subjects in each group were 41 (controls), 31 (ZPP $\leqslant 5 \mu \mathrm{g} / \mathrm{g} \mathrm{Hb})$, and $10(Z P P>5 \mu \mathrm{g} / \mathrm{g} \mathrm{Hb})$. The mean duration of exposure of the two lead subgroups were 13.7 and 14.9 years respectively. ${ }^{\star}$ Significantly different from the control group.

a diminished synthesis of $P G E_{2}$ and 6-keto-PGF $F_{1 x}$ in the kidney together with an enhanced production of $\mathrm{TXB}_{2}$. Thus $\mathrm{Pb}$ might produce changes in the renal metabolism of eicosanoids that mimic those occurring in essential hypertension.

The most remarkable is that effects on excretion of eicosanoids in urine are already detectable at exposures to $\mathrm{Pb}$ that are rather low. This finding might be relevant for the current controversy on the effects of $\mathrm{Pb}$ on blood pressure in the general population. ${ }^{3738}$ The early effects on urinary excretion of 6-keto-PGF ${ }_{1 x}$ and $\mathrm{TXB}_{2}$ suggest that the initial insult in $\mathrm{Pb}$ nephropathy might also involve the vasculature and glomeruli, and is not exclusively localised in the tubulointerstitial compartment. The changes in the renal synthesis of eicosanoids raise the question of their relevance to health. Are these changes the reflection of an ongoing degenerative process that may lead to a loss of renal function or do they simply represent biochemical effects of $\mathrm{Pb}$ without any clinical significance? The failure in the present study to show any significant renal impairment in the workers exposed to $\mathrm{Pb}$, despite the application of a large battery of markers, is more in favour of the second hypothesis. It should be stressed, however, that changes in prostaglandin production, which normally exert little influence on renal haemodynamics, may have deleterious consequences in conditions of decreased renal perfusion. Therefore it is possible that the changes reported may precipitate the decline in renal function only at exposure levels to $\mathrm{Pb}$ giving rise to additional nephrotoxic effects or 
when the kidney is submitted to other toxic insults.

Another mechanism that has been postulated in the development of $\mathrm{Pb}$ hypertension is a reduced synthesis of kallikrein. ${ }^{39}$ The urinary activity of this vasodilation mediating enzyme has been found to be decreased in workers with heavy exposure to $\mathrm{Pb} .{ }^{39-41}$ In the present study, however, as in a previous one, ${ }^{42}$ no effect of exposure to $\mathrm{Pb}$ on urinary kallikrein activity could be found, even when the exposed group was subdivided into young and old workers (results not shown). Thus if kallikrein is involved in the haemodynamic response to exposure to $\mathrm{Pb}$, it is probably from an exposure level higher than that interfering with production of eicosanoids.

The increased urinary excretion of sialic acid also appears as a rather early effect of exposure to $\mathrm{Pb}$. An increase in urinary sialic acid has also been seen in cadmium workers with proteinuria. ${ }^{27} 43$ In workers exposed to $\mathrm{Pb}$, the enhanced excretion of sialic acid cannot be explained by an increased urinary output of plasma proteins or enzymes as no abnormality was found in these parameters. The hypothesis of a biochemical disturbance, unrelated to renal function, appears more probable. As most urinary sialic acid is bound to glycoproteins or glycoderivatives, it would be interesting to identify the specific constituents responsible for the increase of sialic acid in urine.

In conclusion, the early renal effects of occupational exposure to $\mathrm{Pb}$ found in the present study consist of decreased urinary excretion of 6-keto-PGF $F_{1 x}$ associated with enhanced excretion of thromboxane. The relevance to health of these biochemical alterations, detectable at very low exposure to $\mathrm{Pb}$, remains to be established. In view of the lack of any sign of renal dysfunction, however, it is possible that these changes in eicosanoid metabolism correspond to reversible biochemical effects and may only contribute to the degradation of renal function from the onset of the clinical $\mathrm{Pb}$ nephropathy. Another effect found in workers exposed to $\mathrm{Pb}$, which might deserve further investigation, is the significant increase in urinary sialic acid.

\section{Appendix}

CONVERSION OF UNITS

$\begin{array}{ll}\text { Lead } & 1 \mu \mathrm{g}=4.83 \mathrm{nmol} \\ \text { Cadmium } & 1 \mu \mathrm{g}=8.90 \mathrm{nmol} \\ \text { Mercury } & 1 \mu \mathrm{g}=4.99 \mathrm{nmol} \\ \text { Creatinine } & 1 \mathrm{~g}=8.84 \mathrm{mmol}\end{array}$

This study was supported by the Commission of the European Communities (contract No EV4V-0173-B (GDF)), the Fonds National de la Recherche Scientifique, and the Services de la Programmation de la Politique Scientifique (Belgium).

A Cárdenas was supported by a sectorial grant of the Commission of the European Communities.
Requests for reprints to: $\mathrm{R}$ Lauwerys, Industrial Toxicology and Occupational Medicine Unit, Catholic University of Louvain, 30.54 Clos Chapelle-aux-Champs, B-1200 Brussels, Belgium.

1 Lilis R, Gavrilescu N, Nestorescu B, Dumitriu C, Roventa A. Nephropathy in chronic lead poisoning. Br J Ind Med 1968; 25:196-202.

2 Cramer K, Goyer RA, Jagenburg R, Wilson MH. Renal ultrastructure, renal function, and parameters of lead toxicity in workers with different periods of lead exposure. $\mathrm{Br} J$ Ind Med 1974;31:113-27.

3 Wedeen RP, Maesaka JK, Weiner B, et al. Occupational lead nephropathy. Am J Med 1975;59:630-41.

4 Ramirez-Cervantes B, Embree TW, Hine CH, Nelson JW, Varner MO, Putnam RD. Health assessment of employees with different body burdens of lead. J Occup Med 1978;20: 610-7.

5 Wedeen RP, Mallik DK, Batuman V. Detection and treatment of occupational lead nephropathy. Arch Intern Med 1979;139: 53-7.

6 Baker EL, Landrigan PJ, Barbour AG, et al. Occupational lead poisoning in the United States: clinical and biochemical findings related to blood lead levels. $\mathrm{Br} J$ Ind Med 1979; 36:314-22.

7 Lilis R, Valciukas J, Fischbein A, Andrews G, Selikoff IJ, Blumberg W. Renal function impairment in secondary lead smelter workers: correlations with zinc protoporphyrin and blood lead levels. J Environ Pathol Toxicol 1979;2:1447-74.

8 Pinto de Almeida AR, Carvalho FM, Spinola AG, Rocha H. Renal dysfunction in Brazilian lead workers. Am J Nephrol 1987;7:455-8.

9 Bennet WM. Lead nephropathy. Kidney Int 1985;28:212-20.

10 Ritz E, Mann J, Stoeppler M. Lead and the kidney. Adv Nephrol 1988;17:241-74.

11 Goyer RA. Mechanism of lead and cadmium nephrotoxicity. Toxicol Lett 1989;46:153-62.

12 Agency for Toxic Substances and Disease Registry. Toxicological Profile for lead. Atlanta, GA: US Public Health Services, Department of Health and Human Services. 1990 ATSDR/TP-88/17.

13 Yu TF. Lead nephropathy and gout. Am J Kidney Dis 1983; 2:555-8.

14 Nuyts GD, Daelemans RA, Jorens PhG, Elseviers MM, Van de Vyver FL, De Broe ME. Does lead play a role in the development of chronic renal disease? Nephrol Dial Transplant 1991;6:307-15.

15 Hammond PB, Lerner SI, Gartside PS, et al. The relationship of biological indices of lead exposure to the health status of workers in a secondary lead smelter. J Occup Med 1980; 22:475-84.

16 Goyer RA, Weinberg CR, Victery WM, Miller CR. Lead induced nephrotoxicity: kidney calcium as an indicator of tubular injury. In: Bach PH, Lock EA, eds. Nephrotoxicity: in vitro to in vivo: animals to man. New York: Plenum Press, 1989:11-20.

17 Cárdenas A, Roels H, Bernard AM, et al. Markers of early renal changes induced by industrial pollutants. I Application to workers exposed to mercury vapour. Br J Ind Med 1993; 50:17-27

18 Lauwerys R, Delbroeck R, Vens MD. Automated analysis of delta-aminolaevulinic acid in urine. Clin Chim Acta 1972;40: 443-7.

19 Buchet JP, Roels H, Bernard A, Lauwerys R. Assessment of renal function of workers exposed to inorganic lead, cadmium or mercury vapor. J Occup Med 1980;22:741-50.

20 Greenberg A, Parkinson DK, Fetterolf DE, et al. Effects of elevated lead and cadmium burdens on renal function and calcium metabolism. Arch Environ Health 1986;41:69-76.

21 Nuyts GD, D'Haese PC, Elseviers MM, Dr Broe ME. Renal dysfunction and lead exposure. Am J Nephrol 1989;9:85-6.

22 Omae K, Sakurai H, Higashi T, Muto T, Ichikawa M, Sasaki N. No adverse effects of lead on renal function in lead-exposed workers. Ind Health 1990;28:77-83.

23 Mutti A, Lucertini S, Valcavi P, et al. Urinary excretion of brush-border antigen revealed by monocolonal antibody: early indicator of toxic nephropathy. Lancet 1985;ii:914-7.

24 Meyer BR, Fischbein A, Rosenman K, Lerman Y, Drayer DE, Reidenberg MM. Increased urinary enzyme excretion in workers exposed to nephrotoxic chemicals. Am J Med 1984; 76:989-98. 
25 Ong CN, Endo G, Chia KS, Phoon WO, Ong HY. Evaluation of renal function in workers with low blood lead levels. In: Foá V, Emmet EA, Maroni M, Colombi A, eds. Occupational and Environmental Chemical Hazards, Chichester: Ellis Horwood, 1987.

26 Verschoor M, Wibowo A, Herber F, Van Hemmen J, Zielhuis R. Influence of occupational low-level lead exposure on renal parameters. Am J Ind Med 1987;12:341-51.

27 Roels H, Bernard AM, Cárdenas A, et al. Markers of early renal changes induced by industrial pollutants. III. Application to workers exposed to cadmium. Br J Ind Med 1993;50:37-48.

28 Buchet JP, Lauwerys R, Roels $\mathrm{H}$, et al. Renal effects of cadmium body burden of the general population. Lancet 1990;336: 699-702.

29 Khalil-Manesh F, Gonick HC, Weiler E, et al. Early indicators of lead nephropathy. In: Bach PH, Lock EA, eds. Nephrotoxicity: in vitro to in vivo: animals to man. New York: Plenum Press, 1989:119-26.

30 Hong CD, Hanenson IB, Lerner S, Hammond PB, Pesce AJ, Pollak VE. Occupational exposure to lead: Effects on renal function. Kidney Int 1980;18:489-94.

31 Vacca CV, Hines JD, Hall III PW. The proteinuria of industrial lead intoxication. Environ Res 1986;41:440-6.

32 Huang J, He F, Wu Y, Zhang S. Observation on renal function in workers exposed to lead. Sci Total Environ 1988;71:535-7.

33 Mason MJ, Somervaille LJ, Tennant DR, Chettle DR, Scott MC. In-vivo bone lead measurements and renal effects. In: Bach PH, Lock EA eds. Nephrotoxicity: in vitro to in vivo: animals to man. New York: Plenum Press, 1989:113-8.

34 Stoff JS. Prostaglandins and hypertension. Am J Med 1986;80 (suppl 1A):56-61.
35 Patrono C, Dunn MJ. The clinical significance of inhibition of renal prostaglandin synthesis. Kidney Int 1987;32:1-12.

36 Raymond $\mathrm{KH}$, Lifschitz MD. Effect of prostaglandins on renal salt and water excretion. Am J Med 1986;80 (suppl 1A):22-33.

37 Victery W, ed. Symposium on lead-blood pressure relationships, April 27-29, 1987, Chapel Hill, NC. Environ Health Perspect 1988;78:1-155.

38 Sharp DS. Blood lead concentration, renal function, and blood pressures in London civil servants Br J Ind Med 1990;47:790 (letter).

39 Boscolo P, Porcelli G, Cecchetti G, Salimei E, Iannaccone A. Urinary kallikrein activity of workers exposed to lead. $\mathrm{Br} J$ Ind Med 1978;35:226-9.

40 Boscolo P, Galli G, Iannaccone A, Martino F, Porcelli G, Troncone L. Plasma renin activity and urinary kallikrein excretion in lead-exposed workers as related to hypertension and nephropathy. Life Sci 1981;28:175-84.

41 Chmielnicka J, Komsta-Szumska E, Szymanska JA. Arginase and kallikrein activities as biochemical indices of occupational exposure to lead. $B r J$ Ind Med 1981;38:175-8.

42 Roels HA, Lauwerys RR, Buchet JP, Bernard AM, Lijnen P, Van Houte $G$. Urinary kallikrein activity in workers exposed to cadmium, lead, or mercury vapour. Br J Ind Med 1990; 47:331-7.

43 Cárdenas A, Bernard A, Lauwerys R. Disturbance of sialic acid metabolism by chronic exposure to cadmium and its relation with proteinuria. Toxicol Appl Pharm 1991;108:547-58.

Accepted 2 March 1992 